\title{
MANAJEMEN RISIKO, DEWAN DIREKSI, KOMITE AUDIT DAN KINERJA PERUSAHAAN PERBANKAN
}

\author{
Yolanda Limena ${ }^{1}$, Rizky Eriandani ${ }^{2}$ \\ Akuntansi, Fakultas Bisnis dan Ekonomika, Universitas Surabaya \\ Email: s130318075@student.ubaya.ac.id
}

\begin{abstract}
ABSTRAK
Penelitian dilakukan dengan tujuan mengetahui bagaimana pengaruh manajemen risiko, dewan direksi dan komite audit terhadap kinerja perusahaan. Hingga saat ini masih terjadi kesenjangan dan perpaduan variabel antara manajemen risiko dan tata kelola yang masih jarang dilakukan. Penelitian ini menggunakan sektor perbankan yang terdaftar pada Bursa Efek Indonesia periode tahun 2018 - 2020 dengan sampel sebesar 95 perusahaan. Hasil dari penelitian ini menunjukkan manajemen risiko dengan indikator risiko kredit dan risiko likuiditas berpengaruh secara negatif terhadap kinerja perusahaan. Semakin besar kedua risiko ini, maka kinerja bank akan semakin menurun. Selain itu, untuk tata kelola yang diproksikan dengan kepemilikan dewan direksi, ukuran komite audit dan rapat komite audit tidak memiliki pengaruh terhadap kinerja perusahaan. Sedangkan untuk variabel ukuran dewan direksi memiliki pengaruh secara negatif terhadap kinerja perusahaan yang menandakan semakin banyak jumlah dewan direksi maka kinerja akan semakin terhambat
\end{abstract}

\section{Kata Kunci: ROA, Risiko, Direksi, Komite}

\begin{abstract}
The study aims to determine how effect of the risk management, the board of directors and audit committees affect the company's performance. There is still a rare gap and not many studies of combination of risk management and governance. This Study uses all banking sectors listed on Indonesia Stock Exchange (BEI) for 2018 - 2020 and sample of 95 companies. The results of this study suggest that risk management with credit risk indicator and liquidity risk are negative and significant on company performance. The greater the risk, the lower the performance of the bank will be. Furthermore, for corporate governance with the ownership of the board of directors, the size of the audit committee and audit committee meetings has no effect on company performance. As for variables in size, the board of directors has a negative and significant on the performance of the company, which suggests that the more the number of board members is likely to be stunting.
\end{abstract}

\section{Keywords: ROA, Risk, Directors, Committe}

\section{PENDAHULUAN}

Kinerja perusahaan merupakan keberhasilan suatu perusahaan atas kegiatan operasionalnya. Hal ini dilihat dari efektifitas dan efisiensi perusahaan dari waktu ke waktu yang salah satunya dipengaruhi oleh Good Corporate Governance (GCG) yang merupakan pondasi bagi implementasi tata kelola yang baik (Adiati \& Adiwibowo, 2017,p.1). Keadaaan dari kinerja perusahaan mencerminkan bagaimana praktik tata kelola dan telah sesuai dengan tujuan dari perusahaan. Konsep tata kelola (Good Corporate Governance) muncul pertama kali di Indonesia pada akhir tahun 1990-an saat krisis moneter menerjang perekonomian di negara Asia. Perusahaan yang memiliki masalah ekonomi dalam perusahaannya akan dapat berpengaruh pada tingkat kepercayaan masyarakat dan investor di pasar modal sehingga perusahaan harus meningkatkan kinerja perusahaannya (Widyatama \& Wibowo, 2015, p.1). Maka dari itu, perbaikan dalam tata kelola seperti kerangka dari tata kelola, pemegang saham, transparansi informasi, dan tanggung jawab dari dewan direksi dan komite diperlukan secara 
komprehensif (Roadmap OJK 2014). Untuk mendapatan tata kelola yang efektif, pemangku kepentingan dan shareholder dapat bekerjasama dalam mengambil keputusan yang sesuai agar dapat meningkatkan kinerja perusahaan (Hadistya \& Hardika, 2021). Namun perlu diingat jika dapat terjadi konflik keagenan akibat adanya tujuan yang tidak sama antara agen (manajer perusahaan) dan prinsipal (pemegang saham) serta perbedaan informasi yang dimiliki oleh agen dan prinsipal. Selain itu, konflik juga dapat timbul karena adanya manajemen risiko yang merupakan salah satu faktor yang memengaruhi tingkat kinerja perusahaan, dimana perusahaan harus mampu untuk menganalisis kemungkinan risiko yang dapat terjadi (Cahyaningtyas \& Sasanti, 2019).

Manajemen risiko merupakan hal yang penting dalam pencapaian maupun tujuan dari suatu perusahaan karena perusahaan yang menerapkan program risiko atau manajemen nilai pada pemegang saham dapat meningkatkan kinerja dari perusahaan (Musallam, 2020) Pada umumnya sektor perbankan memiliki tingkat risiko jauh lebih besar dibandingkan sektor lainnya karena terdapat regulasi khusus serta batasan dari Bank Indonesia (BI) agar bank dapat dikatakan sehat. Beberapa kriteria untuk menyatakan bank itu sehat adalah jika risiko kredit (NPL) yang memiliki kriteria dari Bank Indonesia adalah kurang dari 5\% dan risiko likuiditas (LDR) memiliki standar minimum 78\% dan maksimum 92\%. Menurut POJK No 18/POJK.03/2016 tentang Penerapan Manajemen Risiko bagi Bank Umum dimana kegiatan bank senantiasa menghadapi risiko sebagai lembaga keuangan. Perbankan merupakan industri kepercayaan dimana kekuatan sistem dari perbankan yang menjadi syarat utama bagi pertumbuhan ekonomi serta stabilitas dapat berjalan dengan baik sehingga nasabah yang mendapatkan informasi, bisa memberikan kepercayaan pada bank (Putera, 2020). Namun, pada tahun 2020 Bank Bukopin mengalami keluhan dari sebagian besar nasabahnya. Para nasabah juga melakukan upaya untuk menarik uang simpanan mereka dari Bank Bukopin secara bersamaan. Hal ini membuat pengawas industri keuangan, OJK (Otoritas Jasa Keuangan dan manajemen dari Bank Bukopin berupaya meyakinkan bahwa kondisi bank baik - baik saja.

Dari kasus ini tercermin adanya konflik keagenan dari agen dan principal dimana asimetri informasi terjadi. Penarikan dana secara bersamaan dalam jumlah besar dapat berakibat pada likuiditas bank menjadi terguncang. Hal ini juga akan berdampak dan berpengaruh pada perekonomian negara. Oleh sebab itu, penting bagi perusahaan perbankan untuk melakukan transparansi dan mempertahankan kinerja dari perusahaannya agar dapat terus beroperasi. Perusahaan perlu mengelola manajemen risiko dan menerapkan GCG secara optimal agar kinerja perusahaan dapat tercapai (Cahyaningtyas \& Sasanti, 2019) (Ekadjaja \& Ekadjaja, 2020). Pada penelitian ini manajemen risiko yang akan diteliti adalah NPL (Non-performing Loan) dan LDR (Loan to Deposit Rasio) serta struktur dari tata kelola yang diteliti adalah dewan direksi dan komite audit. Objek penelitian yang digunakan adalah perusahaan sektor perbankan yang terdaftar pada Bursa Efek Indonesia (BEI) untuk periode 2018 - 2020. Berdasarkan pengetahuan peneliti, variabel manajemen risiko dan tata kelola masih jarang diteliti secara bersama - sama pada penelitian sebelumnya.

Berdasarkan permasalahan yang ada, tujuan dari penelitian ini adalah untuk mengetahui apakah manajemen risiko (NPL, LDR); dewan direksi (kepemilikan saham, ukuran) berpengaruh terhadap kinerja perusahaan; komite audit (ukuran, rapat) berpengaruh terhadap kinerja perusahaan pada sektor perbankan yang terdaftar di BEI periode $2018-2020$. Penelitian ini diharapkan dapat memberikan manfaat sebagai bahan rujukan pada penelitian berikutnya terkait dengan kinerja keuangan yang berhubungan dengan manajemen risiko dan tata kelola perusahaan. Selain itu, penelitian ini juga diharapkan dapat menjadi pengetahuan dan dijadikan pertimbangan bagi manajemen maupun investor saat mengambil keputusan maupun mengidentifikasi hal-hal yang berkaitan dengan kinerja perusahaan. 


\section{TINJAUAN LITERATUR DAN PERUMUSAN HIPOTESIS}

Risiko kredit (NPL) merupakan risiko kegagalan dari pihak lain untuk pemenuhan kewajiban terhadap bank. Semakin besar tingkat NPL maka risiko kredit yang dimiliki oleh suatu bank semakin tinggi sehingga mencerminkan kinerja perusahaan yang tidak baik (Cahyaningtyas \& Sasanti, 2019). Hal ini bertentangan dengan hasil penelitian (Nurfauziah \& Mulyati, 2021)

Risiko likuiditas (LDR) merupakan risiko yang diakibatkan ketidakmampuan dari bank dalam memenuhi kewajiban jatuh tempo yang berasal dari sumber pendanaan arus kas atau dari aset likuid yang digunakan dengan tidak menganggu aktivitas serta kondisi bank (POJK No.18/POJK.03/2016). Hal ini menandakan bahwa semakin tinggi nilai LDR maka menunjukkan kondisi likuiditas yang buruk dari perusahaan serta dapat menyebabkan turunnya kinerja perusahaan. Hasil bertentangan dengan (Kansil et al., 2017) (Ismanto, 2019) yang menyatakan tidak ada pengaruh.

Dewan direksi merupakan hal yang penting dalam struktur dan tata kelola dalam perusahaan untuk melindungi perusahaan serta pemegang saham (Musallam, 2020). Dalam penelitian ini dewan direksi diproksikan dengan kepemilikan saham dewan direksi yang mana semakin tinggi tingkat kepemilikan dari dewan direksi maka direksi akan memiliki motivasi tinggi untuk meningkatkan kinerja dalam perusahaan. Hal ini juga menandakan bahwa antara pihak manajemen dan pemegang saham dapat meminimalisir munculnya konflik keagenan dikarenakan pihak manajemen akan mengusahakan untuk meningkatkan kinerja bagi kesejahteraan pemegang saham termasuk dirinya (Mardiyati \& Murdayanti, 2017) (Musallam, 2020). Hal bertentangan (Fadillah, 2017) yang menyatakan bahwa semakin tinggi kepemilikan saham manajerial dapat menurunkan kinerja perusahaan.

Ukuran dewan direksi merupakan mekanisme yang penting untuk menentukan kinerja perusahaan (Sukandar, 2014). Semakin tinggi jumlah dewan direksi dalam suatu perusahaan akan dapat meningkatkan kinerja perusahaan (Musallam, 2020). Hasil ini tidak selaras dengan (Cindy et al., 2020) yang menyatakan bahwa ukuran dewan direksi tidak memiliki pengaruh bagi meningkatnya kinerja perusahaan.

Adanya komite memiliki manfaat untuk melaksanakan tugas lebih rinci dengan memusatkan pada cara pengelolaan (Governance) dari manajemen. Dalam penelitian ini akan berfokus pada komite audit. Dalam penelitian ini, komite audit diproksikan dengan ukuran komite audit. Ukuran komite audit diharapkan dapat memberikan hasil dan fungsi pengawasan agar dapat mengurangi masalah agensi dan perilaku manajer yang dapat merugikan perusahaan (Rahmawati \& Handayani, 2017). Hasil ini tidak sejalan dengan (Fransisca W, 2013) (Hartono \& Nugrahanti, 2014) yang menyatakan bahwa ukuran komite audit tidak memiliki pengaruh terhadap meningkatnya kinerja.

Selanjutnya, rapat komite audit. Dalam Peraturan Otoritas Jasa Keuangan Nomor 55/POJK.04/2015 tentang Pembentukan dan Pedoman Pelaksanaan Kerja Komite audit disampaikan bahwa komite audit mengadakan rapat minimal 1 kali dalam 3 bulan. Semakin sering komite audit melakukan rapat maka akan tercipta kinerja yang baik (Musallam, 2020). Hasil ini tidak selaras dengan penemuan (Cindy et al., 2020) yang menyatakan bahwa tidak adanya pengaruh dari keduanya

\section{PENGEMBANGAN HIPOTESIS}

\section{Pengaruh Risiko Kredit terhadap kinerja perusahaan}

Risiko kredit terjadi dikarenakan bank meminjamkan kredit ke debitor dan memungkinkan risiko bahwa debitor dalam kewajibannya tidak membayar kembali yang dapat berakibat keuntungan bank dapat menurun (Ekadjaja \& Ekadjaja, 2020). Hal ini akan berakibat pada keputusan yang dibuat oleh investor, dikarenakan dana yang mereka alirkan pada suatu pihak berdasarkan dengan keamanan dan dapat memberikan keuntungan. Dengan demikian, bank memiliki tanggung jawab untuk memberikan keuntungan serta mengelola dana yang diberikan berupa kredit. Selain itu, semakin tinggi NPL maka risiko kredit dalam bank juga 
semakin tinggi sehingga bank harus dapat menanggung rugi yang ada (Cahyaningtyas \& Sasanti, 2019). Selain itu, Pernyataan ini didukung dengan hasil penelitian yang dilakukan oleh (Kansil et al., 2017) yang menyatakan bahwa NPL berpengaruh negatif terhadap kinerja perusahaan. Berdasarkan pernyataan diatas, maka hipotesis yang didapat sebagai berikut:

H1 : Risiko kredit berpengaruh negatif terhadap kinerja perusahaan

\section{Pengaruh Risiko Likuiditas terhadap kinerja perusahaan}

Risiko likuiditas merupakan risiko yang terjadi karena bank tidak mampu memenuhi kewajibannya dalam sumber pendanaan yang telah jatuh tempo. Pengelolaan dalam likuiditas merupakan masalah yang cukup rumit dikarenakan dana kelolaan bank dalam kegiatan operasi adalah dana dalam jangka pendek dan dapat ditarik kapanpun oleh masyarakat (Cahyaningtyas \& Sasanti, 2019). Hal ini dapat diartikan bahwa masyarakat telah mengalami krisis kepercayaan pada bank tersebut dan dapat menimbulkan konflik keagenan . Penarikan dana jika terjadi lebih besar dari yang diperkirakan maka bank akan menghadapi krisis likuiditas. Apabila krisis ini tidak dapat ditangani, kelangsungan perbankan akan terancam. Semakin tinggi tingkat LDR maka menunjukkan bagaimana kondisi bank buruk dan dapat mengakibatkan kinerja menurun. Pernyataan ini selaras dengan hasil penelitian (Revita, 2018) (L. Sari et al., 2020). Berdasarkan pernyataan diatas, maka diperoleh hipotesis sebagai berikut:

H2: Risiko likuiditas berpengaruh negatif terhadap kinerja perusahaan

\section{Pengaruh kepemilikan dewan direksi terhadap kinerja perusahaan}

Menurut (Jensen \& Meckling, 1976) dalam (Musallam, 2020), kepemilikan dewan akan dapat membantu mengurangi masalah agensi serta dapat meningkatkan kinerja suatu perusahaan dengan pengurangan konsumsi pribadi. Berdasarkan teori agensi, kepemilikan dewan direksi dapat membantu dalam mengurangi masalah keagenan serta juga memabntu dalam meningkatkan kinerja perusahaan dengan mensejahterakan kepentingan pemegang saham termasuk dirinya sendiri menurut (Jensen \& Meckling, 1976) dalam (Musallam, 2020).Saham yang dimiliki oleh direktur dapat memotivasi dewan direksi untuk lebih meningkatkan kinerja dalam perusahaan (Chou, 2015) dalam (Mardiyati \& Murdayanti, 2017). Dewan direksi yang memiliki kepemilikan dalam suatu perusahan dapat membuat keputusan yang berdampak pada kekayaan miliknya (Musallam, 2020). Pernyataan ini didukung dengan hasil penelitian (Mardiyati \& Murdayanti, 2017) yang menyatakan kepemilikan saham dewan direksi memiliki pengaruh positif terhadap kinerja perusahaan. Berdasarkan teori dan uraian diatas, maka hipotesis yang didapat sebagai berikut:

H3: Kepemilikan dewan direksi berpengaruh positif terhadap kinerja perusahaan

\section{Pengaruh ukuran dewan direksi terhadap kinerja perusahaan}

Di Indonesia memiliki perbedaaan mekanisme dengan Europe. Hal ini terlihat dari Indonesia menganut two-tier board system dimana terdapat perbedaan peran yang dimiliki oleh dewan direksi dan dewan komisaris sedangkan Europe menganut one-tier board system. Dewan direksi merupakan salah satu peran yang sangat penting dalam perusahaan. dalam mekanisme Corporate Governance, ukuran dewan direksi merupakan mekanisme yang penting untuk menentukan kinerja perusahaan (Sukandar, 2014). Teori agency mengatakan bahwa ukuran dewan penting untuk ditentukan agar dapat menghasilkan kinerja yang baik dan efisien (Apriliani \& Dewayanto, 2018). Ukuran dewan direksi diperlukan karena semakin tinggi jumlah dewan direksi dalam suatu perusahaan akan dapat meningkatkan kinerja perusahaan (Musallam, 2020).

Berdasarikan teori dan uraian diatas, maka hipotesis yang didapat sebagai berikut:

H4: Ukuran dewan direksi berpengaruh positif terhadap kinerja perusahaan 


\section{Pengaruh ukuran komite audit terhadap kinerja perusahaan}

Dalam mengukur ukuran komite audit dilakukan dengan jumlah anggota komite audit yang ada dalam perusahaan. Menurut (Braiotta, 2000) dan (Kalbers \& Fogarty 1993) dalam (Musallam, 2020) mengungkapkan bahwa ukuran komite audit yang besar dapat mengantarkan arah status dan otoritas dalam organisasi yang lebih besar. Pada Bursa Efek Indonesia (BEI) telah memberikan himbauan bagi perusahaan yang tercatat untuk wajib memiliki komite audit. Komite audit merupakan komite yang dibentuk oleh dewan komisaris dan membantu dalam memperkuat menjalankan fungsi pengawasan atas pelaporan keuangan dalam perusahaan, pelaksanaan audit dan penerapan tata kelola di perusahaan (Riniati, 2015). Berdasarkan teori dan uraian diatas, maka hipotesis yang didapat sebagai berikut:

H5: Ukuran komite audit berpengaruh positif terhadap kinerja perusahaan

\section{Pengaruh Rapat Komite Audit terhadap kinerja perusahaan}

Komite audit memiliki pengaruh dan peran yang penting bagi perusahaan. Dengan adanya komite audit dapat meningkatkan pengendalian dalam perusahaan. Perusahaan yang mempunyai komite audit cenderung transparan dan lebih terbuka (Widyatama \& Wibowo, 2015). Komite audit dalam menjalankan tugas dan tanggung jawab memerlukan rapat untuk berkomunikasi dan mengkoordinasikan fungsi mereka dalam perusahaan. Dalam Peraturan Otoritas Jasa Keuangan Nomor 55/POJK.04/2015 tentang Pembentukan dan Pedoman Pelaksanaan Kerja Komite audit disampaikan bahwa komite audit mengadakan rapat minimal 1 kali dalam 3 bulan. Seringnya rapat yang diadakan oleh komite audit akan tercipta koordinasi sehingga fungsi akan terlaksana dan menciptakan kinerja perusahaan yang baik. Berdasarkan teori dan uraian diatas, maka hipotesis yang didapat sebagai berikut:

H6: Rapat Komite berpengaruh positif terhadap kinerja perusahaan

\section{METODE}

Populasi dalam penelitian ini adalah seluruh sektor perbankan yang terdaftar di Bursa Efek Indonesia. Metode yang digunakan dalam pengambilan sampel adalah non-probability purposive adjustment sample. Kriteria yang ditetapkan sebagai berikut, pertama - Perusahaan yang telah mempublikasikan annual report (laporan tahunan perusahaan) di website BEI dan website perusahaan. Kedua, perusahaan yang menerbitkan laporan tahunan pada periode 2018 2020. Ketiga, perusahaan menggunaan mata uang rupiah dalam melaporkan keuangannya. Keempat, perusahaan dengan laporan keuangan berakhir pada 31 Desember. Kelima, perusahaan yang memiliki informasi lengkap sesuai dengan kebutuhan untuk mencari nilai dalam variable yang digunakan. Total sampel yang didapat sebanyak 99 tahun perusahaan.

Variabel Dependen pada penelitian adalah kinerja perusahaan yang diukur dengan indikator keuangan, yaitu Return On Asset (ROA) merupakan determinan yang sebenarnya pada perusahaan. Variabel independen yang digunakan adalah risiko kredit dengan pengukuran kredit bermasalah dibagi dengan total kredit. Risiko likuiditas dengan pengukuran kredit yang diberikan pada pihak ketiga dan tidak termasuk pada bank lain dibagi dengan dana pihak ketiga. Kepemilikan dewan direksi diukur dengan menggunakan persentase saham yang dimiliki oleh direksi diperusahaan pada periode tersebut. Ukuran dewan direksi dengan menggunakan jumlah anggota dewan direksi dalam perusahaan tersebut. Ukuran komite audit dengan pengukuran jumlah anggota komite audit dalam perusahaan. Serta rapat komite audit diukur dengan jumlah pertemuan komite audit dalam satu (1) tahun dalam perusahaan.

Dalam penelitian ini menggunakan variabel kontrol berupa usia perusahaan yang diukur dengan natural logaritma dari usia perusahaan, ukuran perusahaan dengan logaritma alami ukuran perusahaan dan debt ratio dengan total liabilities dibagi dengan total aset.

Penelitian ini merupakan penelitian yang menggunakan pendekatan kuantitatif. Populasi dalam penelitian ini adalah perusahaan dengan sektor perbankan yang terdaftar di Bursa Efek Indonesia (BEI) yang menyediakan laporan keuangan dan annual report selama tiga (3) tahun, yaitu 2018- 2020. Data dalam penelitian ini diperoleh dari website BEI (www.idx.co.id) dan 
website resmi perusahaan. Dalam menentukan sampel, penelitian ini menggunakan metode purposive sampling. Pengolahan data dilakukan dengan menggunakan SPSS 23.

\section{METODE ANALISIS}

Dalam melakukan uji, peneliti menggunakan regresi berganda dengan asumsi OLS (Ordinary Least Square). Persamaan model sebagai berikut:

$$
\begin{array}{ll}
\mathrm{ROA}_{\mathrm{it}} \quad=B_{0}+B_{1} N P L_{\mathrm{it}}+B_{2} L D R_{\mathrm{it}}+B_{3} D O_{\mathrm{it}}+B_{4} D S_{\mathrm{it}} B_{5} \mathrm{ACSIZE}_{\mathrm{it}}+B_{6} \mathrm{ACM}_{\mathrm{it}}+\quad B_{7} \mathrm{FAGE}_{\mathrm{it}}+ \\
& B_{8} \mathrm{FSIZE}_{\mathrm{it}}+B_{9} \mathrm{DEBT}_{\mathrm{it}}+e_{i t}
\end{array}
$$

Dengan penjelasan:
ROA $=$ Net Income sebelum tax dan bunga dibagi total asset
$\mathrm{NPL}_{\text {it }} \quad=$ Persentase risiko kredit dalam perusahaan dalam tahun $\mathrm{t}$
$\mathrm{LDR}_{\mathrm{it}} \quad=$ Persentase risiko likuiditas dalam perusahaan dalam tahun $\mathrm{t}$
$\mathrm{DO}_{\mathrm{it}} \quad=$ Persentase kepemilikan saham dewan direksi dalam perusahan dalam
tahun $\mathrm{t}$
$\mathrm{DS}_{\text {it }} \quad=$ Jumlah dewan direksi perusahaan dalam tahun $\mathrm{t}$
ACSIZE $_{\text {it }}=$ Jumlah audit komite perusahaan dalam tahun $\mathrm{t}$
$\mathrm{ACM}_{\mathrm{it}} \quad=$ Jumlah rapat komite audit dalam tahun $\mathrm{t}$
FAGE $_{\text {it }} \quad=$ Logaritma natural dari usia perusahaan
FSIZE $_{\text {it }} \quad=$ Logaritma natural dari total aset
$\mathrm{DEBT}_{\text {it }} \quad=$ Total liabilitas dibagi dengan total aset perusahaan dalam tahun $\mathrm{t}$

\section{HASIL DAN PEMBAHASAN \\ HASIL PENELITIAN}

Berdasarkan pada kriteria yang telah ada, sampel yang kiranya sesuai dalam penelitian adalah 99 data. Setelah melakukan model regresi, terdapat 97 data untuk regresi 1 dan model regresi kedua sebanyak 95 data. Berikut merupakan proses dalam pemilihan sample yang digunakan untuk penelitian.

Tabel 1. Statistik Deskriptif

\begin{tabular}{|l|c|c|c|c|c|}
\hline Variabel & $\mathrm{N}$ & Min & Max & Mean & Std. Deviation \\
\hline ROA & 99 & -.0923244 & .0313434 & .004672569 & .0207945070 \\
\hline NPL & 99 & .0000000 & .1016000 & .019838394 & .0174983948 \\
\hline LDR & 99 & .3933000 & 1.6310000 & .888414141 & .2086404103 \\
\hline DO & 99 & .0000000 & .0093000 & .000257842 & .0010390052 \\
\hline DS & 99 & 3 & 12 & 6.43 & 2.774 \\
\hline ACSIZE & 99 & 3 & 8 & 3.74 & 1.036 \\
\hline ACM & 99 & 3 & 30 & 11.44 & 6.531 \\
\hline FAGE & 99 & .69314718 & 3.63758616 & 2.5294117292 & .70096335666 \\
\hline FSIZE & 99 & 27.22256174 & 34.95208045 & 31.4231218208 & 1.79813967857 \\
\hline DEBT & 99 & .4350000 & .9320000 & .821727273 & .0736347603 \\
\hline
\end{tabular}

Nilai minimum pada variable ROA (Return On Assets) adalah sebesar 0.0923244 yang dimiliki oleh Bank Jago Tbk tahun 2019. Nilai maksimum sebesar 0.0313434 dimiliki oleh Bank Central Asia Tbk tahun 2018. Hasil yang ada menandakan bahwa Bank Jago Tbk 
memiliki kinerja perusahaan yang kurang baik dan efektif dimana kemampuan manajemen perusahaan dalam mendapatkan profit masih terbilang lemah sedangkan pada Bank Central Asia Tbk melakukan kinerja perusahaan dengan baik sehingga dapat menghasilkan profit paling besar. Rata - rata Return On Assets yang dilakukan oleh perseroan pada sektor perbankan adalah 0.0046725569 yang menandakan rata - rata perseroan melakukan peningkatan profit.

Nilai minimum pada variable NPL (Non Perfoming Loan) adalah 0.000000 yang dimiliki oleh Bank Jago Tbk tahun 2020 dan nilai maksimum sebesar 0.1016000 oleh Allo Bank Indonesia Tbk tahun 2020. Rata - rata perseroan pada sektor perbankan memiliki tingkat risiko kredit sebesar 0.19838394. Nilai minimum untuk variable LDR (Loan to Funding Ratio) adalah sebesar 0,3933000 dimiliki oleh Bank Capital Indonesia Tbk tahun 2020 dan nilai maksimum sebesar 1.6310000 dimiliki oleh Bank BTPN Tbk tahun 2019. Hal ini menandakan bahwa Bank Capital Indonesia Tbk memiliki tingkat risiko likuiditas yang rendah dibandingkan dengan Bank BTPN Tbk yang memiliki tingkat risiko lebih besar. Rata - rata perseroan pada sektor perbankan memiliki tingkat risiko likuiditas sebesar 0.888414141 .

Nilai minimum pada variabel kepemilikan dewan direksi adalah sebesar 0.0000000 oleh Bank Jago Tbk tahun 2018 - 2019, Bank MNC Internasional Tbk tahun 2018 - 2020, Bank Capital Indonesia tahun 2018 - 2020, Allo Bank Indonesia Tbk tahun 2018 - 2020, Bank KB Bukopin Tbk tahun 2018 - 2019, Bank Negara Indonesia (Persero) tahun 2020, Bank Rakyat Indonesia tahun 2020, Bank Neo Commerce Tbk tahun 2018 - 2020, Bank Pembangunan Daerah Banten tahun 2018 - 2020, Bank Ganesha Tbk tahun 2018 - 2020, Bank Pembangunan Daerah Jawa Barat Tbk tahun 2018, Bank Maspion Indonesia Tbk tahun 2018 - 2020, Bank Bumi Arta Tbk tahun 2018, Bank CIMB Niaga tahun 2018 - 2020, Bank Maybank Indonesia Tbk tahun 2018 - 2020, Bank Permata Tbk tahun 2018 - 2020, Bank of India Indonesia Tbk tahun 2018 - 2020, Bank BTPN Tbk tahun 2019 - 2020, Bank Victoria Internasional Tbk tahun 2018 - 2020, Bank China Construction Bank tahun 2018 - 2020, Bank Mega Tbk tahun 2018 - 2020, Bank Nationalnobu Tbk tahun 2018 - 2020 dan Bank Woori Saudara Indonesia tahun 2018 - 2020 yang menandakan pada perseroan tidak terdapat dewan direksi yang memiliki saham. Nilai maksimal pada variabel ini dimiliki oleh Bank BTPN tahun 2018 yang berarti pada perseroan ini memiliki jumlah kepemilikan saham dewan direksi paling besar daripada perseroan lainnya. Rata - rata kepemilikan dewan direksi yang dimiliki oleh perseroan adalah 0,0010390052. Nilai minimum pada variabel ukuran dewan direksi adalah sebesar 3 milik Bank Jago Tbk tahun 2018 - 2019, Bank MNC Internasional Tbk tahun 2018, Allo Bank Indonesia Tbk tahun 2020, Bank Pembangunan Daerah Banten tahun 2019 - 2020, Bank Ganesha Tbk tahun 2018 - 2020, Bank Bumi Arta Tbk tahun 2018 - 2020, hal ini berarti bahwa pada sektor perbankan perseroan diatas memiliki jumlah dewan direksi dengan jumlah minimum yang sesuai dengan peraturan Bank Indonesia. Nilai maksimum pada variabel ini adalah 12 milik Bank Central Asia Tbk tahun 2018 dan 2020, Bank Negara Indonesia (Persero) tahun 2020, dan Bank Rakyat Indonesia (Persero) tahun 2018 - 2019, yang menandakan bahwa perseroan ini memiliki jumlah dewan direksi lebih besar dari lainnya.

Nilai minimum pada variable ukuran komite audit adalah sebesar 3 dan nilai maksimum yang ada adalah 8. Nilai minimum dimiliki oleh Bank Rakyat Indonesia Argoniaga tahun 2018 - 2020, Bank Jago Tbk tahun 2018 - 2020, Bank Capital Indonesia Tbk tahun 2018 - 2020, Bank Central Asia Tbk tahun 2018 - 2020, Allo Bank Indonesia Tbk tahun 2018 - 2020, Bank Mestika Dharma Tbk tahun 2018 - 2020, Bank Neo Commerce Tbk tahun 2018 - 2020, Bank Pembangunan Daerah Jawa Barat tahun 2018, Bank Maspion Indonesia Tbk tahun 2018 - 2020, Bank Bumi Arta Tbk tahun 2018 - 2020, Bank CIMB Niaga Tbk tahun 2020, Bank Maybank Indonesia Tbk 2018 - 2020, Bank Sinarmas Tbk tahun 2018 - 2020, Bank of India Indonesia Tbk tahun 2018 - 2020, Bank BTPN Tbk tahun 2019, Bank Victoria Internasional Tbk tahun 2018 - 2020, Bank Mayapada Internasional Tbk tahun 2018 - 2020, Bank China Construction Bank tahun 2018 - 2020, Bank Mega Tbk tahun 2018 - 2020, Bank Pan Indonesia Tbk tahun 2018 - 2019 yang berarti jumlah komite audit dalam perseroan tersebut sesuai dengan minimal yang diterapkan oleh Bank Indonesia dan nilai maksimum dimiliki oleh Bank Rakyat Indonesia 
(Persero). Rata - rata dari ukuran komite audit adalah 4. Nilai minimum pada variabel rapat komite audit adalah sebesar 3 yang dimiliki oleh Bank Neo Commerce Tbk tahun 2018. Nilai maksimum variabel ini dimiliki oleh Bank Rakyat Indonesia Argoniaga tahun 2018. Hal ini menandakan bahwa jumlah rapat yang dilakukan Bank Neo Commerce Tbk paling rendah dibandingkan dengan Bank Rakyat Indonesia Argoniaga yang memiliki tingkat jumlah rapat yang paling tinggi diantara perseroan lain. Rata - rata dari rapat komite audit pada penelitian ini adalah 11 .

Tabel 2. Uji F dan Uji Koefisien Determinasi

\begin{tabular}{|l|l|l|}
\hline Uji F & Sig & $.000^{\mathrm{b}}$ \\
\hline Uji R-Square & Adjusted R-Square & .554 \\
\hline
\end{tabular}

Dari nilai Uji $\mathrm{F}$ dapat ditunjukkan bahwa nilai signifikansi untuk model regresi penelitian ini adalah 0,000 yang memiliki arti variabel NPL, LDR, DO, DS, ACSIZE, ACM, FAGE, FSIZE, DEBT terbukti terdapat pengaruh secara simultan / secara bersama - sama terhadap kinerja perusahaan. Berdasarkan hasil regresi diatas, dapat menunjukkan bahwa nilai Adjusted R Square sebesar 0,554 yang artinya variabel NPL, LDR, DO, DS, ACSIZE, ACM, FAGE, FSIZE, DEBT dapat menjelaskan variabel dependen (Kinerja Perusahaan) 55,4\%. Nilai $44,6 \%$ akan terjelaskan melalui variabel atau sebab lain diluar model dari penelitian

\section{PEMBAHASAN}

Nilai dari NPL dengan tingkat yang tinggi menunjukkan kualitas bank yang buruk karena jumlah kredit yang besar dapat mengakibatkan penurunan laba (Cahyaningtyas \& Sasanti, 2019). Hasil uji menunjukkan bahwa variabel NPL secara signifikan memiliki pengaruh negatif terhadap kinerja perusahaan. Oleh karena itu, hipotesis pertama dari penelitian ini diterima. Besar atau tidak NPL yang dilakukan perusahaan memiliki pengaruh terhadap peningkatan kinerja perusahaan. Hasil ini sejalan dengan penelitian terdahulu (Ekadjaja \& Ekadjaja, 2020) serta (Kansil et al., 2017). Hasil ini tidak sejalan dengan penelitian (Cahyaningtyas \& Sasanti, 2019) dan (Ristati \& Nurul Mahfuzah, 2018). Dengan tingginya LDR dapat menunjukkan kondisi likuiditas suatu bank juga buruk. Hal ini dikarenakan penempatan kredit dari pihak ketiga dapat ditarik sewaktu - waktu (Cahyaningtyas \& Sasanti, 2019). Hasil dari penelitian ini menunjukkan LDR berpengaruh negatif dan signifikan terhadap kinerja perusahaan. Semakin tinggi rasio LDR maka semakin turun tingkat pengembalian laba. Hal ini menyebabkan kinerja juga semakin kecil. dalam Hasil ini sejalan dengan penelitian terdahulu (L. Sari et al., 2020) dan (Revita, 2018). Hasil ini tidak sejalan dengan(Kansil et al., 2017), (Fahlevi \& Suria Manda, 2021). 
Tabel 3. Uji Hipotesis

\begin{tabular}{|c|c|c|c|c|c|}
\hline & \multicolumn{2}{|c|}{$\begin{array}{l}\text { Unstandardized } \\
\text { Coefficients }\end{array}$} & \multirow[t]{2}{*}{$\begin{array}{l}\text { Standardized } \\
\text { Coefficients }\end{array}$} & \multirow{2}{*}{$\mathrm{t}$} & \multirow{2}{*}{ Sig. } \\
\hline & B & $\begin{array}{l}\text { Std. } \\
\text { Error }\end{array}$ & & & \\
\hline (Constant) & -.148 & .049 & & -2.993 & .002 \\
\hline NPL & -.503 & .098 & -.424 & -5.108 & .000 \\
\hline LDR & -.011 & .006 & -.141 & -1.836 & .035 \\
\hline DO & -.113 & 1.196 & -.007 & -.094 & .4625 \\
\hline DS & -.002 & .001 & -.355 & -1.981 & .0255 \\
\hline ACSIZE & -.001 & .001 & -.078 & -.934 & .1765 \\
\hline $\mathrm{ACM}$ & .000 & .000 & -.123 & -1.440 & .0765 \\
\hline FAGE & -.001 & .002 & -.025 & -.258 & .3985 \\
\hline FSIZE & .008 & .002 & .850 & 4.054 & .000 \\
\hline DEBT & -.055 & .024 & -.186 & -2.264 & .013 \\
\hline
\end{tabular}

Kepemilikan saham direktur dapat memotivasi serta meningkatkan kinerja dalam perusahaan (Mardiyati \& Murdayanti, 2017). Hal ini sejalan dengan penelitian terdahulu (Mardiyati \& Murdayanti, 2017) dan (Musallam, 2020). Hasil penelitian, dapat disimpulkan bahwa variabel kepemilikan saham tidak berpengaruh signifikan terhadap kinerja perusahaan yang diproksikan dengan ROA. Artinya, hipotesis ketiga ditolak. Kepemilikan saham dewan direksi tidak memiliki pengaruh terhadap kinerja perusahaan. Kepemilikan saham manajerial di Indonesia masih cenderung rendah (Fadillah, 2017). Hal ini terlihat dari rata - rata prosentase kepemilikan yang berkisar $2-3 \%$ setiap tahunnya. Teori agensi menyatakan bahwa ukuran dewan penting untuk menentukan kinerja yang baik dan efisien (Apriliani \& Dewayanto, 2018). Pembagian tugas dapat lebih terarah dan berfokus pada bidang masing-masing. Hal ini sejalan dengan penelitian terdahulu oleh (Musallam, 2020) dan (Khoirunnisa \& Karina, 2021). Hasil pengujian dari variabel ukuran dewan direksi menunjukkan bahwa secara signifikan berpengaruh negatif terhadap kinerja perusahaan. Hipotesis ke-empat ditolak. Artinya, besarnya ukuran dewan direksi memberikan pengaruh bagi kinerja perusahaan dan dapat menimbulkan permasalahan agensi dengan komunikasi dan koordinasi dan pengawasan menjadi sulit dilakukan. Hasil ini sejalan dengan penelitian oleh (Fadlilah et al., 2020)

Komite audit merupakan salah satu komite yang memiliki tugas untuk membantu dewan komisaris menjalankan fungsi pengawasan dalam kinerja perusahaan (FCGI,2019). Hasil dari penelitian ini menunjukkan bahwa variabel ukuran komite tidak berpengaruh terhadap kinerja perusahaan yang diproyeksikan dengan ROA. Dengan demikian, hipotesis ke-lima ditolak. Hal ini menunjukkan bahwa banyak atau sedikitnya jumlah komite audit dalam perusahaan tidak akan mempengaruhi kinerja perusahaan pada sektor perbankan periode 2018 2020. Hasil ini juga sejalan dengan penelitian sebelumnya (Hartono \& Nugrahanti, 2014) dan (Novitasari et al., 2017). Hasil ini bertentangan dengan (Shanti, 2020) dan (A. M. Sari et al., 2016). Hasil dari pengujian menunjukkan variabel rapat komite audit tidak berpengaruh terhadap kinerja perusahaan yang diproyeksikan dengan ROA. Dengan demikian, hipotesis keenam ditolak. Hasil ini menunjukkan bahwa frekuensi rapat yang dilakukan oleh komite audit tidak akan mempengaruhi kinerja perusahaan pada sektor perbankan periode 2018 - 2020. Hasil 
ini sejalan dengan penelitian (Adiati \& Adiwibowo, 2017) dan (Cindy et al., 2020) yang menyatakan bahwa jumlah rapat komite audit tidak mencerminkan kinerja yang baik tetapi dapat mengindikasi masalah baru dikarenakan harus menyatukan berbagai pendapat dan dinilai kurang efektif. Hasil ini tidak sejalan dengan penelitian yang dilakukan (Musallam, 2020).

\section{PENUTUP}

Hasil penelitian yang dilakukan menunjukkan NPL (Non Performing Loan), LDR (Loan to Funding Ratio) dan ukuran dewan direksi berpengaruh secara negate terhadap kinerja perusahaan. Sedangkan kepemilikan saham dewan direksi, ukuran komite audit dan rapat komite audit tidak berpengaruh terhadap kinerja perusahaan. Penelitian ini memiliki keterbatasan, yaitu pada kinerja perusahan hanya diukur dengan menggunakan ROA (Return On Asset), pengukuran manajemen risiko hanya menggunakan 2 dari 8 indikator yang ditetapkan Bank Indonesia, objek penelitian yang digunakan masih terbatas dengan sektor perbankan serta kurang mencerminkan pengaruh kinerja perusahaan karena tata kelola hanya menggunakan indikator kepemilikan saham dan ukuran dewan direksi serta ukuran dan rapat komite audit. Keterbatasan yang ada dalam penelitian ini dapat menjadi saran bagi penelitian berikutnya agar dapat meneliti tidak hanya pada perusahaan perbankan tetapi juga non-keuangan. Menggunakan proksi lain untuk kinerja perusahaan, seperti Return On Equity (ROE) dan PER (Price to Earning Ratio) agar mendapatkan hasil yang lebih komprehensif untuk mengukur kinerja perusahaan. Selain itu, juga diharapkan dapat menambah variabel independen lainnya baik tata kelola maupun manajemen risiko sehingga mendapatkan pengetahuan mengenai faktor lain.

\section{DAFTAR PUSTAKA}

Adiati, Y., \& Adiwibowo, A. (2017). Pengaruh Karakteristik Komite Audit Terhadap Kinerja Perusahaanperbankan Di Bursa Efek Indonesia Tahun 2013 - 2015. Diponegoro Journal of Accounting, 6(4), 363-377.

Apriliani, M. T., \& Dewayanto, T. (2018). Pengaruh tata kelola perusahaan dan ukuran perusahaan terhadap kinerja keuangan perusahaan artikel ilmiah. Diponegoro Journal of Accounting, 7(1), 1-10.

Cahyaningtyas, S. R., \& Sasanti, E. E. (2019). Manajemen, Penerapan Bank, Resiko Kelola, Tata Dan, Perusahaan Perusahaan, Kinerja Ekonomi, Fakultas Mataram, Universitas. Jurnal Aplikasi Akuntansi, 3(2), 170-206.

http://jaa.unram.ac.id/index.php/jaa/article/view/52

Cindy, D., Lestari, A., Yatminiwati, M., Komisaris, D., Audit, K., Kinerja, D., Committee, A., \& Performance, F. (2020). Pengaruh Good Corporate Governance Terhadap Kinerja. Journal of Accounting, 3(1), 47-51.

Ekadjaja, A., \& Ekadjaja, M. (2020). Tata Kelola Perusahaan, Risiko Keuangan, dan Kinerja Perbankan di Indonesia. Jurnal Ekonomi, 25(3), 391-412. https://doi.org/10.24912/je.v25i3.687

Fadillah, A. R. (2017). Terhadap Kinerja Perusahaan Yang Terdaftar Di Lq45. Jurnal Akuntansi, 12, 37-52.

Fadlilah, T. I. N., Setiono, H., \& Dafiq, M. B. I. (2020). Pengaruh Good Corporate Governance dan Ukuran Perusahaan Terhadap Kinerja Perusahaan (Studi Empiris Pada Perusahaan Manufaktur Makanan dan Minuman Yang Terdaftar Di Bursa Efek Indonesia Periode 2016-2019). Skripsi, Universitas Islam Majapahit, Mojokerto.

Fahlevi, D., \& Suria Manda, G. (2021). Pengaruh Manajemen Risiko Terhadap Kinerja Keuangan Bank Swasta Yang Terdaftar Di Bursa Efek Indonesia (Bei). Jbmi, 17(3), 253268. 
Fransisca W, M. (2013). Pengaruh Dewan Direksi, Komisaris Independen, Komite Audit, Kepemilikan Manajerial dan Kepemilikan Institusional Terhadap Kinerja Keuangan. Jurnal Ilmu Manajemen (JIM), 1(1), 234-249.

Hadistya, I. D., \& Hardika, M. (2021). Analisis Penerapan Tata Kelola Perusahaan Yang Baik Pada PT Bank Central Asia Tbk. Jurnal Pendidikan Tambusai, 5(2013), 3414-3421.

Hartono, D. F., \& Nugrahanti, Y. W. (2014). Pengaruh Mekanisme GCG terhadap Kinerja Keuangan Perusahaan Perbankan. Dinamika Akuntansi, Keuangan Dan Perbankan, 3(2), 191-205.

Ismanto, D. (2019). Pengaruh Penerapan Manajemen Risiko terhadap Kinerja Keuangan Sektor Perbankan Periode 2013 -2017. Jurnal Fokus, 1(1), 105-112.

Kansil, D., Murni, S., \& Tulung, J. . (2017). ( Bank Pembangunan Daerah se-Indonesia ) Influence Of Risk To Financial Perfomence Year 2013-2015 ( Regional Development Bank In Indonesia ). Jurnal EMBA, 5(3), 3508-3517.

Khoirunnisa, \& Karina, A. (2021). Pengaruh Kepemilikan Institusional, Dewan Komisaris Independen, Komite Audit dan Dewan Direksi terhadap Kinerja Keuangan Perusahaan (Studi Empiris pada Perusahaan BUMN yang terdaftar di Bursa Efek Indonesia pada tahun 2017-2019) (pp. 1-28). Jurnal Ilmu Akuntansi, 19(2).

Mardiyati, U., \& Murdayanti, Y. (2017). Pengaruh Ukuran Dewan, Kepemilikan Saham Oleh Direktur, Dan Jender Terhadap Kinerja Keuangan Perbankan. Jurnal Manajemen, 20(3), 402-415. https://doi.org/10.24912/jm.v20i3.15

Musallam, S. R. M. (2020). Effects of board characteristics, audit committee and risk management on corporate performance: evidence from Palestinian listed companies. International Journal of Islamic and Middle Eastern Finance and Management, 13(4), 691-706. https://doi.org/10.1108/IMEFM-12-2017-0347

Novitasari, I., Endiana, i dewa made, \& Arizona, putu edy. (2017). Pengaruh Mekanisme Good Corporate Governance terhadap Kinerja Keuangan Perusahaan Perbankan yang terdaftar di BEI. Journal of Chemical Information and Modeling, 110(9), 1689-1699.

Nurfauziah, N., \& Mulyati, S. (2021). Pengaruh Penerapan Manajemen Risiko Terhadap Kinerja Keuangan (Studi Pada Bank Umum Kelompok Usaha). Riset \& Jurnal Akuntansi, 11(1), 21-35. https://doi.org/10.37478/als.v11i1.827

Putera, A. P. (2020). Prinsip Kepercayaan Sebagai Fondasi Utama Kegiatan Perbankan. Jurnal Hukum Bisnis Bonum Commune, 3(1), 128-139. https://doi.org/10.30996/jhbbc.v3i1.2984

Rahmawati, N., \& Handayani, R. (2017). Analisis Pengaruh Karakteristik Corporate Governance Terhadap Kinerja Perusahaan (Studi Empiris pada Perusahaan Manufaktur yang Terdaftar di Bursa Efek Indonesia periode 2010-2014). Diponegoro Journal of Accounting, 6(3), 26-37.

Revita, M. L. D. E. (2018). Pengaruh GCG, CAR, LDR Terhadap Kinerja Keuangan Serta Harga Saham Perbankan. Jurnal Ecodemica, 2(2), 156-176.

Ristati, N., \& Nurul Mahfuzah. (2018). Pengaruh Penerapan Manajemen Risiko terhadap Kepuasan Kinerja Keuangan pada Bank Pembangunan Daerah di Indonesia. Jurnal Visioner \& Strategis, 7(1), 41-50.

Sari, A. M., Tugiman, H., \& Nurbaiti, A. (2016). Pengaruh Good Corporate Governance dan Ukuran Perusahaan terhadap Kinerja Perusahaan. Ekspansi, 8(2), 161-172.

Sari, L., Tanno, A., \& Putri, A. (2020). Peran NPL Terhadap Hubungan Antara LDR dan Kinerja Perusahaan (Study Empiris Pada Bank BUMN yang Terdaftar di BEI). Jurnal 
Ilmiah Administrasi Bisnis Dan Inovasi, 3(2), 133-144. https://doi.org/10.25139/jai.v3i2.2081

Shanti, Y. K. (2020). Pengaruh Komite Audit Terhadap Kinerja Keuangan Perusahaan Dengan Dewan Komisaris Sebagai Variabel Intervening. IQTISHADUNA: Jurnal Ilmiah Ekonomi Kita, 9(2), 147-158. https://doi.org/10.46367/iqtishaduna.v9i2.241

Sukandar, P. P. (2014). Pengaruh Ukuran Dewan Direksi dan Dewan Komisaris serta Ukuran Perusahaan Terhadap Kinerja Keuangan Perusahaan (Studi Empiris pada Perusahaan Manufaktur Sektor Consumer Good yang Terdaftar di BEI Tahun 2010-2012). Diponegoro Journal of Accounting, 3(3), 689-695.

Widyatama, B. ., \& Wibowo, A. S. . (2015). Pengaruh Mekanisme Corporate Governance Terhadap. Diponegoro Journal of Accounting, 4(2), 1-11. 